\title{
Concealed Handgun Laws Can Save Lives
}

\author{
John R. Lott, Jr
}

$\mathrm{T}$

O gun control advocates, the logic of opposing concealed handgun laws is straightforward. If guns are introduced into a violent encounter, the probability that someone will die increases. Murders are viewed as arising from unintentional fits of rage that are quickly regretted, and simply keeping guns out of people's reach will prevent deaths. More guns are also seen as leading to more accidental gun deaths. The solution is clear: more regulation or even the complete elimination of guns.

Those who advocate letting law-abiding citizens carry concealed handguns point to polls of American citizens undertaken by organisations like the Los Angeles Times and Gallup showing that Americans defend themselves with guns between 764,000 and $3.6 \mathrm{~m}$ times each year, with the vast majority of cases simply involving people brandishing a gun to prevent attack. Victims (such as women or the elderly) are most often much weaker than the criminals that attack them. Guns are seen by these advocates as the great equaliser, and allowing concealed handguns will provide citizens even greater ability to defend themselves.

Anecdotal evidence is widely available from both sides, with the news regularly containing stories on gun violence. While defensive uses of guns are neither as dramatic nor as frequently reported, these stories have played a large role in inducing 31 states to gamble that concealed handguns will deter crime by guarantecing their citizens the right to carry concealed handguns if they do not have a criminal record or histories of significant mental illness. This constitutes a dramatic increase from the nine states that had these so-called 'shall issue' laws in 1986.

\section{The Lott-Mustard Study}

While the effects described by both sides exist, the question is really what the net effect of such laws is. Are more lives saved or lost as a result of allowing law-abiding citizens to carry concealed handguns?

Anecdotal evidence obviously cannot resolve this debate. To provide a more systematic answer, I recently completed a study with David Mustard, a graduate student at the University of Chicago, analysing the FBI's crime statistics (Lott \& Mustard, 1997). While many studies examine the effects of gun control, and a smaller number of papers specifically address the right to carry concealed firearms, they involve little more than either time-series or cross-sectional evidence comparing mean crime rates, and none controls for variables that normally concern econo-

John Lott is the John M. Olin Law and Economics Fellow at the University of Chicago's School of Law. 
mists (for example, the probability of arrest and conviction and the length of prison sentences or even variables like personal income). Our paper tries to overcome these problems by using annual cross-sectional time-series county level crime data for all 3,054 US counties from 1977 to 1992 to investigate the impact of 'shall issue' right-to-carry firearm laws. It is also the first paper to study the questions of deterrence using these data. While many recent studies employ proxies for deterrence, such as police expenditures or general levels of imprisonment, we are able to use arrest rates by type of crime, and also, for a subset of our data, conviction rates and sentence lengths by type of crime. We also attempt to analyse a question noted but not empirically addressed in this literature: the concern over causality between increases in handgun usage and crime rates. Is it higher crime that leads to increased handgun ownership, or the reverse? The issue is more complicated than simply whether carrying concealed firearms reduces murders because there are questions over whether criminals might substitute between different types of crimes as well as the extent to which accidental handgun deaths might increase.

\section{The Results}

The most conservative estimates show that adopting these 'shall issue' laws reduced murders by 8.5 per cent, rapes by 5 per cent, aggravated assaults by 7 per cent, and robbery by 3 per cent.

To put it another way, if those states which did not have concealed handguns laws in 1992 had adopted them, citizens in those states would have avoided suffering approximately 1,570 murders; 4,177 rapes; over 60,000 aggravated assaults; and 12,000 robberies. Criminals do apparently respond to deterrence.

The benefits of concealed handguns are not limited to those who use a handgun in self-defence. By virtue of the fact of handguns being concealed, criminals are unable to tell whether a potential victim is able to defend herself until they attack, thus making it less attractive for criminals to commit crimes where they come into direct contact with victims. Citizens who have no intention of ever carrying a concealed handgun in a sense 'free ride' off the crime fighting efforts of their fellow citizens.

Yet, while some criminals avoid crimes like robbery after concealed handgun laws are passed, they do not necessarily stop committing crime entirely. Some criminals substitute into crimes where the risks of confronting an armed victim are much lower. Indeed, the drawback of these laws is that while violent crimes fell, property offences like larceny (such as stealing from unattended automobiles or vending machines) and auto theft rose.

Our study also provided some surprises. While support for strict gun control laws has usually been strongest in large cities, right-to-carry laws produced the largest drops in violent crimes in counties with the highest populations and highest crime rates. For example, in counties with populations over 200,000 , concealed handgun laws produced an average drop in murder rates of over 13 per cent. The half of the counties with the highest murder rates experienced over a 10 per cent drop in mur- 
ders. The half of the counties with the highest rape rates saw rapes fall by over 7 per cent.

Concealed handguns also appear to be a great equaliser among the sexes. Murder rates decline when either more women or more men carry concealed handguns, but the effect is especially pronounced for women. An additional woman carrying a concealed handgun reduces the murder rate for women by about three to four times more than an additional man carrying a concealed handgun reduces the murder rate for men. Possibly, this arises because allowing a woman to defend herself with a concealed handgun represents a much larger change in her ability to defend herself than the change created by providing a man with a handgun.

Despite all the attention given to the 1994 Brady Law, which imposed waiting periods on gun purchases across the US, our study is the first to provide direct evidence of the Brady Law's effect on crime rates. Using county level crime and punishment data available up through 1995 for Arizona, we find that the law's implementation is associated with both higher aggravated assault and rape rates. National data on state waiting period laws implies that there is no relationship between either the presence or the length of the waiting period and the level of crime.

We also found evidence on whether more permitted handguns will be used in committing crimes and whether their owners fire shots during heated disputes such as at traffic accidents. The rarity of these incidents is reflected in Florida's statistics: over 300,000 concealed handgun licences were issued between 1 October 1987 and 31 December 1995, but only five violent crimes involving permitted handguns were committed and none of these cases resulted in fatalities.

As for traffic accidents, with evidence now available from 31 states, a few of which have had these laws for many decades, there is still only one recorded incident from earlier this year in Texas, where a permitted handgun was used in a shooting following a traffic accident. Even in that one case, a grand jury found that the shooting was in self-defence, since the driver who did the shooting did so only while he was being beaten by the other driver.

And what about accidental deaths? The number of accidental handgun deaths each year is fewer than 200 . Our estimates imply that if the states without 'shall issue' laws were to adopt them, the increase in accidental handgun deaths would be at most nine more deaths per year. Even the largest possible increase is quite small compared to the at least 1,570 fewer murders that would be produced.

\section{Assessing the Results}

How much confidence do we have in our results? No single study is likely to end the debate on concealed handguns, but ours provides the first systematic national evidence; and the almost 50,000 observations in our data set allow us to control for a range of factors that have never been accounted for in any previous study of crime, let alone any previous gun control study. By contrast, the largest prior study examined only 170 cities within a single year (Kleck \& Patterson, 1993). Among other variables, our regressions control for arrest and conviction rates, prison sen- 
tences, changes in handgun laws such as waiting periods or those imposing penalties when a gun is used in a commission of a crime, income, poverty, unemployment, and demographic changes.

Preventing law-abiding citizens from carrying handguns does not end violence, but merely makes them more vulnerable to being attacked. The very large size and strength of our results should at least give pause to those who oppose concealed handguns. Chances to relax regulations that potentially offer at least 8.5 per cent drops in murder rates are difficult to ignore.

\section{References}

Kleck, G. \& E. Patterson (1993), "The Impact of Gun Control and Gun Ownership Levels on Violence Rates', Journal of Quantitative Criminology 9(3): 249-87.

Lott, J. \& D. Mustard (1997), 'Crime, Deterrence and Right-to-Carry Concealed Handguns', Journal of Legal Studies 26 (forthcoming). 